\title{
A review of Indirect Matrix Converter Topologies
}

\author{
Lazhar Rmili ${ }^{1}$, Salem Rahmani ${ }^{1}$, Kamal Al-Haddad ${ }^{2}$ \\ ${ }^{1}$ Laboratory of Biophysics and Medical Technology (BMT), \\ ISTMT of the University of Tunis El-Manar, Tunisia \\ Av. Dr. Zouhaier Essafi, 1006, Tunisia \\ rmili lazhar@yahoo.fr, rsalem02@yahoo.fr \\ ${ }^{2}$ Canada Research Chair in Energy Conversion and Power Electronics CRC-ECPE, \\ École de Technologie Supérieure, 1100 Notre-Dame, Montréal, Québec H3C 1K3, Canada \\ kamal@ele.etsmtl.ca
}

\begin{abstract}
Matrix Converter (MC) is a modern direct AC/AC electrical power converter without dc-link capacitor It is operated in four quadrants, assuring control of the output voltage, amplitude and frequency. The matrix converter has recently attracted significant attention among researchers and it has become increasingly attractive for applications of wind energy conversion, military power supplies, induction motor drives, etc. Recently, different MC topologies, which have their own advantages and disadvantages, have been proposed and developed. Matrix converter can be classified as direct and indirect structure. In this paper, the indirect MCs are reviewed. Different characteristics of the indirect MC topologies are mentioned to show the strengths and weaknesses of such converter topologies.
\end{abstract}

Keywords- Matrix converter; AC/AC conversion; topologies; bidirectional switches;

\section{INTRODUCTION}

Matrix converter is a new generation of the direct power converter controlling the output voltage, amplitude and frequency. It has an adjustable power factor to control the input, regardless of the load. The absence of heavy and susceptible-tofailure capacitors, matrix converters can perform operations at high temperature, gain reliability, control input and output current and adjust voltage sine waves with an adjustable phase shift. These are considered some advantages of this type of converters. The controlling of output voltage, amplitude and frequency represents one more advantage over the previously mentioned advantages and over other types of converters as well. Those advantages promote the integration of this new topology in several areas of industrial applications. For example, aerospace industries have a great interest in that converter [1], [2], marine propulsion industries, electrical drive machines with variable speed [3]-[10], embedded systems and other fields of renewable energy which are based on wind and fuel cells [11]-[14].

Various research works on the topologies of matrix converters, led to the discovery of appropriate structures that minimize the number of semi- conductors. Two types of topologies for the matrix converter have been established by researchers including direct and indirect matrix converter topologies [15]-[26]. It has been shown that the indirect topology is handled easier. Other studies have been published on the design of multilevel and Z-Source Matrix Converters.

In previous work [24], authors showed the primary concerns of the MCs on bidirectional switches as well as the direct MC topologies and associated modelling. In this paper, the indirect topologies for MCs are investigated. Various features of those topologies are studied and a brief summary of the research will be shown at the end.

\section{INDIRECT MATRIX CONVERTER TOPOLOGY}

A new topology, developed in the early 2000 s, can be proposed as an alternative to the matrix converter. This configuration consists of a combination of two conventional converters through a fictitious intermediate floor without capacitive storage element. It is called "double stage converter". The first floor is a controlled rectifier directly connected to the second floor, which consists of a voltage inverter, traditionally used in variable speed $A C$ machines as presented in figure 1.

This indirect converter topology has two stages:

- Rectifier stage and inverter stage

The rectifier stage is formed of two switching cells, denoted (R) and ( $\left.R^{\prime}\right)$, modeled by the (1). One switch is closed at each switching time for both cells; this condition is expressed by the relation (2).

$$
\left[S_{\text {rect }}\right]=\left[\begin{array}{ccc}
S_{A} & S_{B} & S_{C} \\
S_{A}^{\prime} & S_{B}^{\prime} & S_{C}^{v}
\end{array}\right]
$$

Where .... $\left[S_{\text {redd }}\right]$ is the connection matrix of the rectifier. 
$\left\{\begin{array}{c}S_{A}+S_{B}+S_{C}=1 \\ S_{A}^{\prime}+S_{B}^{z}+S_{C}^{\prime}=1\end{array}\right.$

The operation of the rectifier is described by (3) and (4).

$\left[\begin{array}{l}v_{p} \\ v_{o}\end{array}\right]=\left[S_{\text {rect }}\right]\left[\begin{array}{l}v_{A} \\ v_{B} \\ v_{C}\end{array}\right]$

$\left[\begin{array}{l}i_{A} \\ i_{B} \\ i_{C}\end{array}\right]=\left[S_{\text {rect }}\right]^{T}\left[\begin{array}{c}i_{d c} \\ -i_{d e}\end{array}\right]$

The inverter stage of the indirect matrix converter consists of three switching cells called $a, b, c$ as shown in figure 1 . This floor is modeled by equation (5) and satisfies the constraints described by (6).

$\left[S_{\text {inv }}\right]=\left[\begin{array}{cc}S_{a} & S_{a}^{\prime} \\ S_{b} & S_{b}^{\prime} \\ S_{c} & S_{c}^{\prime}\end{array}\right]$

Where ... $\left[S_{\text {inv }}\right]$ is the connection matrix of the inverter stage.

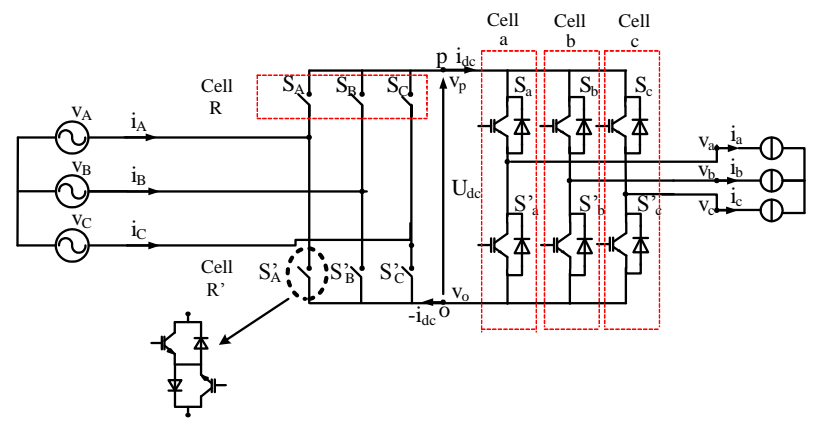

Fig. 1. Dual-stage indirect matrix converter

Every rectifier switch may be one of the following switches Fig. 2

$\left\{\begin{array}{l}S_{a}+S^{s}{ }_{a}=1 \\ S_{b}+S_{b}^{\prime}=1 \\ S_{c}+S_{c}^{z}=1\end{array}\right.$

The inverter operation is set by the relations (7) and (8).

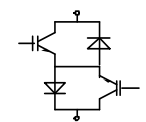

(a) Transistors with common emetters

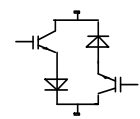

(c) Transistor and diode in series

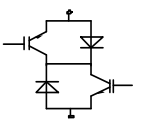

(b) Transistors with common collectors

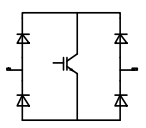

(e) Transistor associated with a diode bridge

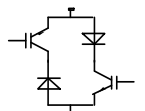

(d) Transistor and diode in series

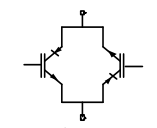

(f) RB-IGBT structure

$$
\left[\begin{array}{l}
v_{a} \\
v_{b} \\
v_{c}
\end{array}\right]=\left[S_{i n v}\right]\left[\begin{array}{l}
v_{p} \\
v_{o}
\end{array}\right]
$$

$\left[\begin{array}{c}i_{d v} \\ -i_{d c}\end{array}\right]=\left[S_{i n v}\right]^{T}\left[\begin{array}{l}i_{a} \\ i_{b} \\ i_{c}\end{array}\right]$

The connection matrix of two-stage matrix converter named $\left[S_{D E}\right]$ is obtained by the product of the connecting matrices of the inverter and rectifier, as shown in equation (9).

$$
\begin{aligned}
& {\left[S_{D E}\right]=\left[S_{\text {inv }}\right] \cdot\left[S_{\text {rect }}\right]=} \\
& {\left[\begin{array}{ll}
S_{a} & S^{v} \\
S_{b} & S_{b}^{t} \\
S_{c} & S^{v}{ }_{b}
\end{array}\right] \cdot\left[\begin{array}{lll}
S_{A} & S_{B} & S_{C} \\
S_{A}^{v} & S^{v} & S^{v}
\end{array}\right]}
\end{aligned}
$$

A tie between two matrices connections can be established as shown in (10).

$[S]=\left[S_{D E}\right] \Rightarrow\left[\begin{array}{lll}S_{A a} & S_{B a} & S_{C a} \\ S_{A b} & S_{B b} & S_{C b} \\ S_{A c} & S_{B c} & S_{C c}\end{array}\right]=$

$\left[\begin{array}{ll}S_{a} & S^{v}{ }_{a} \\ S_{b} & S^{z}{ }_{b} \\ S_{c} & S^{t}{ }_{c}\end{array}\right] \cdot\left[\begin{array}{ccc}S_{A} & S_{B} & S_{C} \\ S_{A}^{v} & S_{B}^{v} & S_{C}^{v}\end{array}\right]$

In the same manner as the direct matrix converter, 
a formulation based on modulation of the switches may also be set for the dual stage matrix converter. The equations described above in "connection function" are transposed in "modulation function" and the conversion matrices defined by the modulation functions of each stage of "dual-stage" matrix converter are described by (11), (12) for the rectifier stage and (15), (16) for the inverter stage.

$m_{i}=\frac{t_{\bar{i}}}{T}$ where $t_{\bar{i}}$ represents the conduction time of switch $\left(S_{i}\right)$ during the commutation period ${ }^{T}$.

$\left[M_{\text {rect }}\right]=\left[\begin{array}{ccc}m_{A} & m_{B} & m_{C} \\ m_{A}^{\prime} & m_{B}^{v} & m_{C}^{e}\end{array}\right]$

$\left\{\begin{array}{l}m_{A}+m_{B}+m_{C}=1 \\ m_{A}^{\prime}+m_{B}^{s}+m_{C}^{\prime}=1\end{array}\right.$

The laws of conversion of electrical values, whatsoever voltage/voltage or current/current are set by relations (13), (14) for the recovery block and (17), (18) for the inverter stage.

$$
\begin{aligned}
& {\left[\begin{array}{l}
v_{p} \\
v_{o}
\end{array}\right]=\left[M_{\text {rect }}\right]\left[\begin{array}{l}
v_{A} \\
v_{B} \\
v_{C}
\end{array}\right]} \\
& {\left[\begin{array}{l}
i_{A} \\
i_{B} \\
i_{C}
\end{array}\right]=\left[M_{\text {rect }}\right]^{T}\left[\begin{array}{c}
i_{\text {red }} \\
-i_{\text {red }}
\end{array}\right]} \\
& {\left[M_{i n v}\right]=\left[\begin{array}{ll}
m_{a} & m_{a}^{s} \\
m_{b} & m_{b}^{v} \\
m_{c} & m_{c}^{v}
\end{array}\right]} \\
& \left\{\begin{array}{l}
m_{a}+m_{a}^{\prime}=1 \\
m_{b}+m_{b}^{g}=1 \\
m_{c}+m_{c}^{\prime}=1
\end{array}\right. \\
& {\left[\begin{array}{l}
v_{a} \\
v_{b} \\
v_{c}
\end{array}\right]=\left[M_{\text {inv }}\right]\left[\begin{array}{l}
v_{p} \\
v_{o}
\end{array}\right]}
\end{aligned}
$$

Fig. 3. Different indirect MC topologies

This two-stage indirect matrix converter structure developed by "J.W. Kollar" has a major advantage which is the ability to minimize the number of power transistors. The different topologies derived from indirect dual-stage $\mathrm{MC}$ have been shown in figure 3 . Based on the two-stage indirect MC configuration, the following topologies have been derived:

\section{A. Indirect matrix converter:}

The configuration shown in figure 4 includes a rectifier stage comprising six bidirectional switches connected to a common emitter or common collector. This configuration generates less switching and conduction losses compared to other 
configurations. It has a complex control for the number of switches to handle. All this leads to the development of other configurations with the aim of reducing the number of required transistors which facilitates the monitoring and control of the matrix converter.

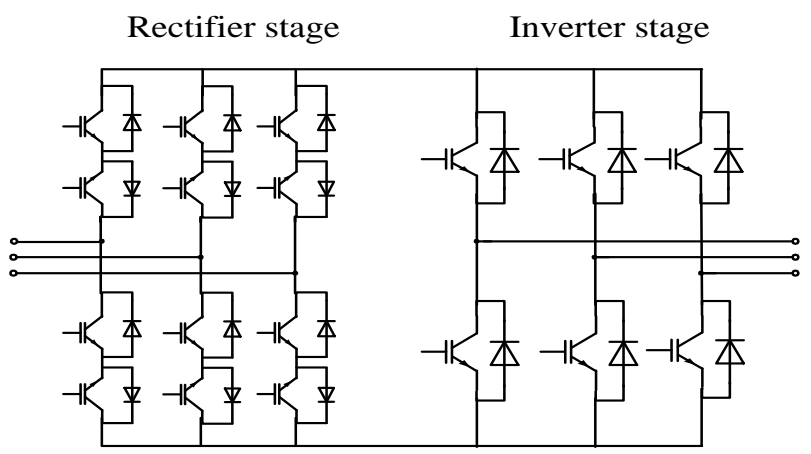

Fig. 4. Indirect matrix converter

\section{B. Sparse matrix converter:}

The configuration shown in figure 5 , leads to remove an IGBT from each arm of the rectifier, so three components will be eliminated totally compared to the previous configuration, which facilitates the development of control algorithm of the converter. Conduction losses will be greater than those generated by the first configuration since three transistors and diodes are working during the feeding phase of the load as well as two transistors and two diodes in the feedback phase to the network.

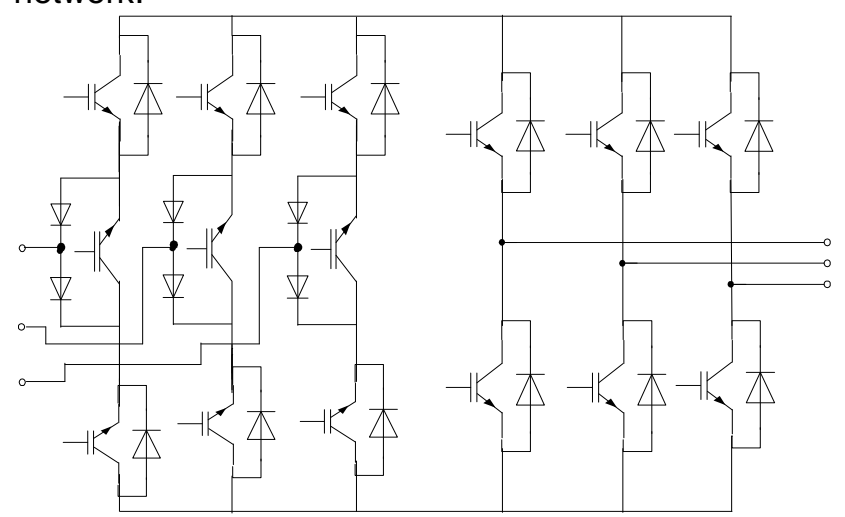

Fig. 5. Sparse Matrix converter

\section{Very-Sparse matrix converter:}

The structure of this topology illustrated in figure 6 is based on the implementation of bidirectional IGBT switches connected to a diode bridge, where the number of the controlled components in the rectifier is reduced compared to the two configurations mentioned above. Each active element of the rectifier requires the activation of a transistor with two diodes in each commutation phase, the rectifier requests two transistors and four diodes, bearing in mind that conduction losses are then a matter of importance.

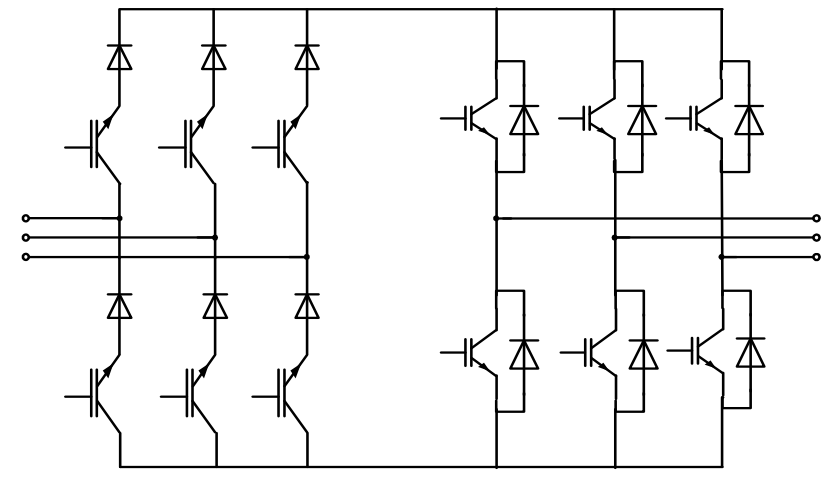

Fig. 6. Very-Sparse Matrix Converter

\section{Ultra-Sparse Matrix Converter:}

In this configuration, the least number of switches is employed. There is a single switch via input phase as shown in figure 7. In each arm, one transistor and two diodes are controlled. This structure generates similar conduction losses to those produced by the "Very- Sparse" structure. Yet, this configuration does not allow bi-directional power flow which limits its practical application.

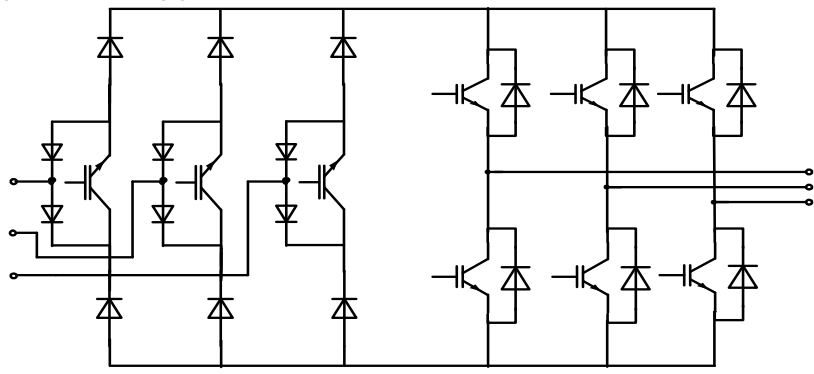

Fig. 7. Ultra-Sparse matrix converter

\section{E. Matrix Converter "to inverter stage"}

The first stage of this configuration includes a rectifier in cascade with an inverter circuit as shown in figure 8. This structure has many controlled components than the "Sparse" topology. It creates additional switching losses and has a high complexity level in control. Consequently, this configuration will not be an objective study.

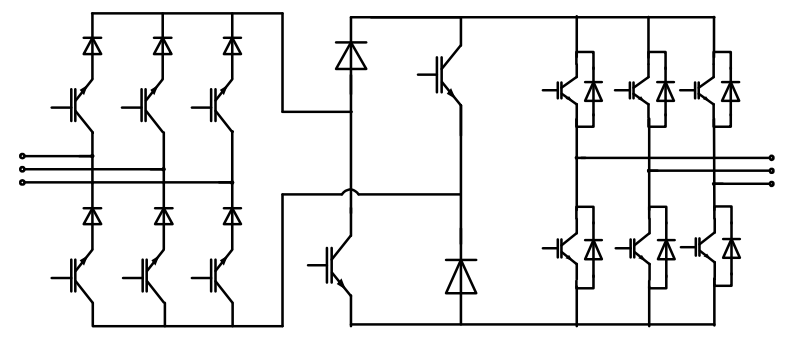

Fig. 8. Matrix converter with rectifier stage

\section{F. Matrix Converter based on RB-IGBT:}

The structure shown in figure 9 incorporates RBIGBTs into the rectifier stage with advantages like reduction of conduction losses. The poor diode recovery behavior of the RB-IGBT is of less concern here than in a matrix converter because it is possible 
to switch the rectifier stage at zero current as soft switching pattern. At low switching frequencies, a matrix converter built with RB-IGBTs will be more efficient than the one built with IGBTs.

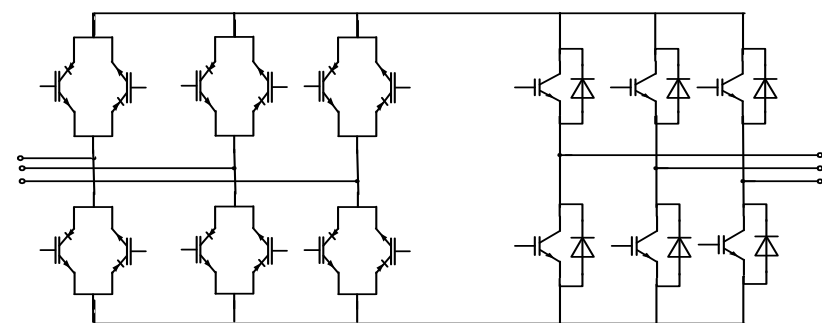

Fig. 9. Matrix converter or rectifier unit switches are based on RBIGBT

\section{G. Matrix Converter based hybrid switches:}

The topology of matrix converter using hybrid bidirectional switches in the rectifier stage (as shown in figure 10), provides low conduction losses in motoring operation as well as soft turn-on commutation of the RB-IGBTs, whereas in the rectifier stage the standard IGBTs and diodes provide low switching losses in regenerative operation.

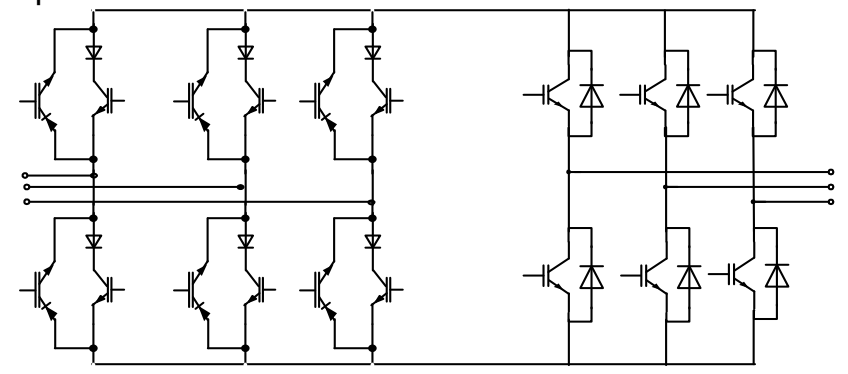

Fig. 10. Matrix converter or rectifier unit switches are based on a RB-IGBT on anti-parallel to an IGBT with a series diode

Table 1 shows the summary of the abovementioned MC topologies considering various points including some elements such as a number of components, power losses, control strategy complexity and reversibility.

\section{SIMULATION RESULTS}

The SimPowerSystem toolbox of MATLAB has been used as the simulation tool. The simulation results before and after compensation of the threelevel sparse matrix converter feeding an $\mathrm{RL}$ load as illustrated in Fig.11, also shown in Figs.12 to 17. Table II gives the system parameters used in the simulations.

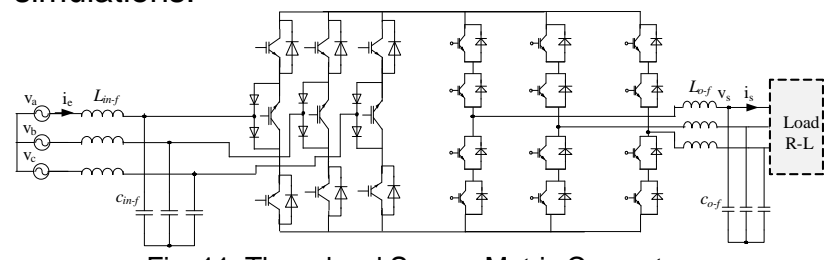

Fig. 11. Three-level Sparse Matrix Converter
Table 1. Summary of the indirect topologies features

\begin{tabular}{|c|c|c|c|c|c|}
\hline Topology & $\begin{array}{c}\text { Numbe } \\
\text { transist } \\
\text { ors }\end{array}$ & $\begin{array}{c}\text { Number } \\
\text { of } \\
\text { diodes }\end{array}$ & $\begin{array}{c}\text { Energetic } \\
\text { losses }\end{array}$ & $\begin{array}{c}\text { Reversibi } \\
\text { lity power }\end{array}$ & Control \\
\hline $\begin{array}{c}\text { Indirect } \\
\text { Matrix }\end{array}$ & 18 & 18 & low & yes & $\begin{array}{c}\text { fairly } \\
\text { complic } \\
\text { ated }\end{array}$ \\
\hline $\begin{array}{c}\text { Sparse } \\
\text { tric }\end{array}$ & 15 & 18 & important & yes & $\begin{array}{c}\text { fairly } \\
\text { complic } \\
\text { ated }\end{array}$ \\
\hline $\begin{array}{c}\text { Very- } \\
\text { Sparse }\end{array}$ & 12 & 12 & low & yes & easy \\
\hline $\begin{array}{c}\text { Ultra- } \\
\text { sparse }\end{array}$ & 9 & 18 & low & No & easy \\
\hline $\begin{array}{c}\text { With Stage } \\
\text { inverter }\end{array}$ & 14 & 14 & important & yes & complic \\
ated \\
\hline $\begin{array}{c}\text { Based on } \\
\text { RB-IGBT }\end{array}$ & 18 & 18 & low & yes & $\begin{array}{c}\text { fairly } \\
\text { complic } \\
\text { ated }\end{array}$ \\
\hline Based-on & 18 & 18 & yes & easy \\
\hline
\end{tabular}

Figs.12 (a)-(b) show the phase a input current (ie) and its harmonic spectrum, respectively. The input current has a THD of $75.33 \%$. The output voltage (vs) of phase (a), and its harmonic spectrum (output voltage THD of $92.21 \%$ ) are shown in figs.13 (a)-(b), respectively. Figs.14 (a)-(b) show the phase (a) output current (is) and its harmonic spectrum. The output current THD is $2.43 \%$. An input and output LC filters are necessary to compensate the highfrequency ripple from the input currents and output voltages. Thus, an LC filter is connected at the input side to avoid overvoltage and to filter the highfrequency ripple from the input currents. Similarly, on the other side, an output LC filter is connected between the converter and the load which allows controlling the output voltage and mitigates its harmonics. Figs. 15 (a) and (b) show the phase (a) input current and its harmonic spectrum after filtering. The measured THD of the input current in phase (a) is reduced from $75.33 \%$ before compensation to $1.78 \%$ after compensation. It is important to notice that the input current is kept free of harmonics. 


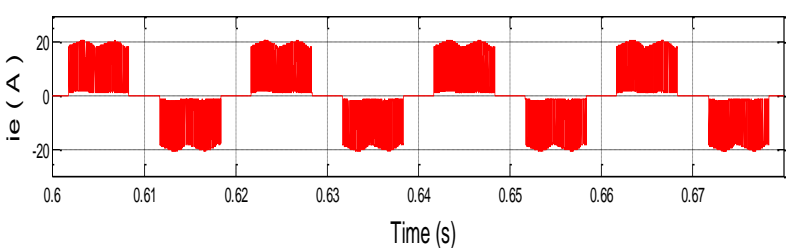

(a)

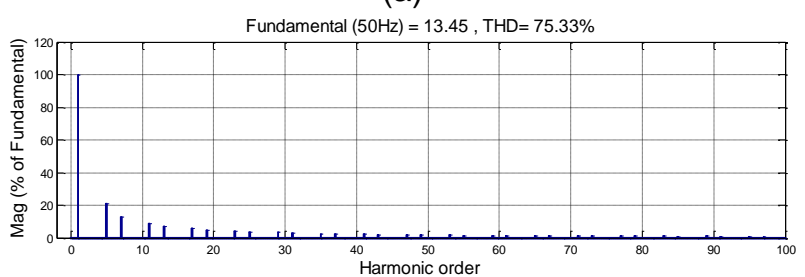

(b)

Fig. 12. (a) Waveform of phase a input current (ie) of three-phase three-level sparse matrix converter before filtering, (b) Harmonic spectrum of input current.

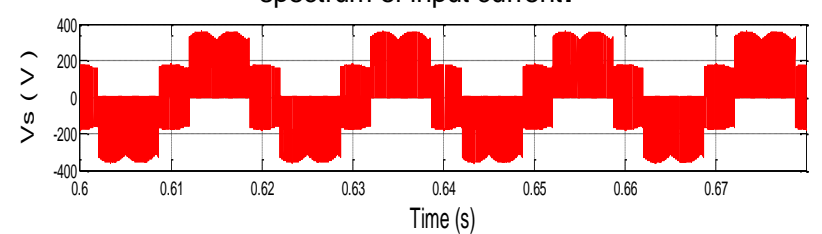

(a)

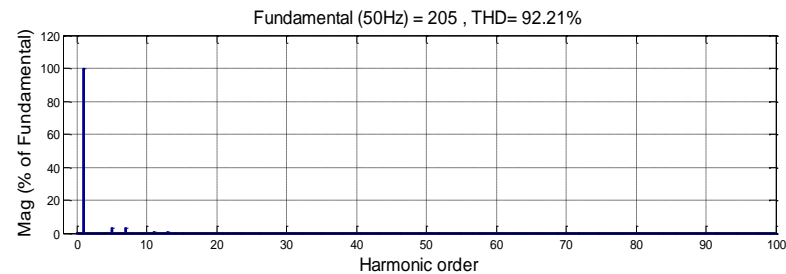

(b)

Fig. 13. (a) Waveform of phase a output voltage (vs) of threephase three-level sparse matrix converter before filtering, (b) Harmonic spectrum of output voltage

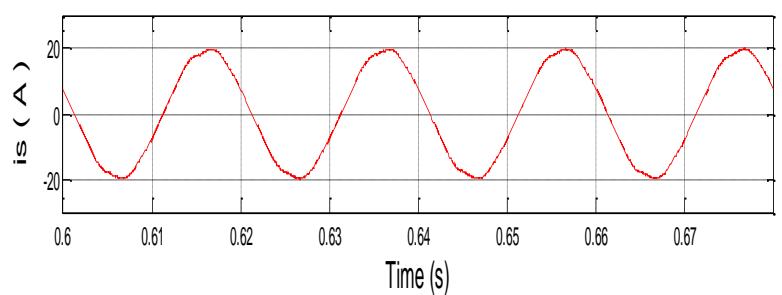

(a)

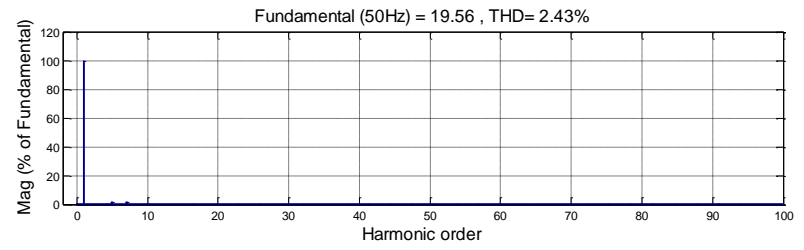

(b)

Fig. 14. (a) Waveform of phase a output current (is) of threephase three-level sparse matrix converter before filtering, (b) Harmonic spectrum of output current.

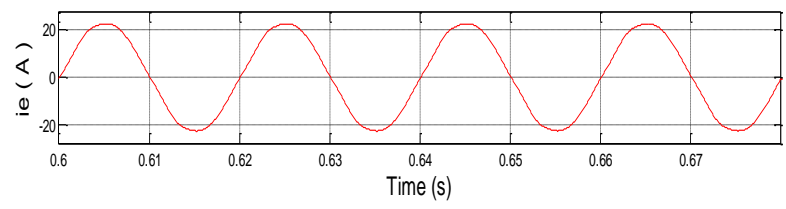

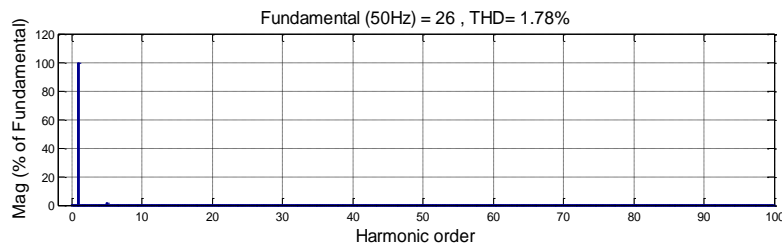

(b)

Fig. 15. (a) Waveform of phase a input current of three-phase three-level sparse matrix converter after filtering, (b) Harmonic spectrum of input current.

The waveforms and harmonic spectra of output voltage and current waveforms after filtering are shown in (figs.16 and 17) respectively. The output filter reduces the THD in the output voltage from $92.21 \%$ to $0.26 \%$. The THD of the output current in phase (a) is therefore reduced from $2.43 \%$ without output filter to $0.15 \%$ after filtering. These results show the output LC filter capability to compensate harmonics of output voltages and output currents.

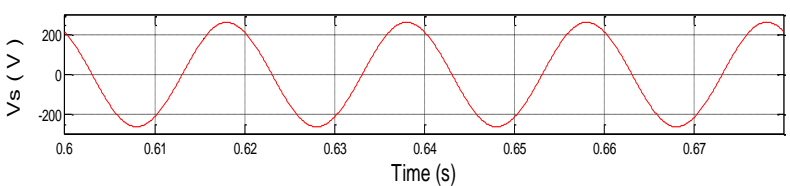

(a)

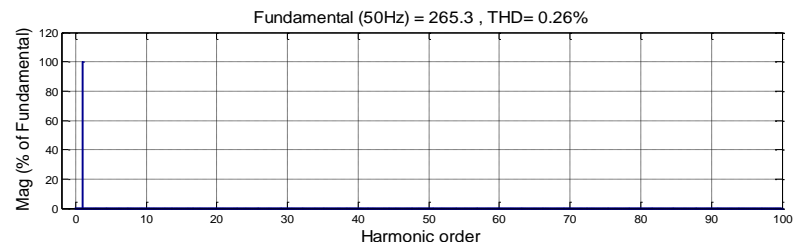

(b)

Fig.16. (a) Waveform of phase a output voltage of three-phase three-level sparse matrix converter after filtering, (b) Harmonic spectrum of output voltage

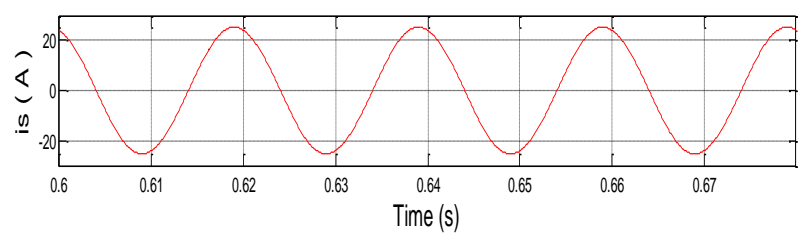

(a)

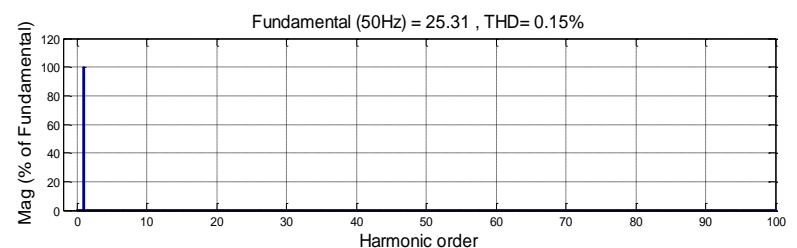

(b)

Fig.17. (a) Waveform of phase a output current of three-phase three-level sparse matrix converter after filtering, (b) Harmonic spectrum of output current

(a) 
Table 2. Specification Parameters

\begin{tabular}{|c|c|}
\hline $\begin{array}{c}\text { Circuit } \\
\text { Specifications }\end{array}$ & Value \\
\hline Input side & $V_{\text {in-max }}=311 \mathrm{~V}, f_{\text {in }}=50 \mathrm{~Hz}$ \\
\hline Load & $R=10 \Omega, L=10 \mathrm{mH}$ \\
\hline Input filter & $\begin{array}{c}R_{\text {in }-f}=0.1 \Omega, L_{\text {in }-f}=40 \mathrm{mH} \\
C_{\text {in-f }}=100 \mu F\end{array}$ \\
\hline Output filter & $\begin{array}{c}R_{0-f}=0.1 \Omega, L_{0-f}=27 \mathrm{mH} \\
C_{0-f}=200 \mu F\end{array}$ \\
\hline Output side & $V_{0-\max }=256.8 \mathrm{~V}, f_{0}=50 \mathrm{~Hz}$ \\
\hline Ratio & 0.825 \\
\hline Switching frequency & $f_{\text {sw }}=10 \mathrm{KHz}$ \\
\hline
\end{tabular}

\section{CONCLUSION}

This paper proves that the dual stage MC topology has been studied and analyzed. Different topologies based on dual stage configuration of MC have been illustrated. The brief summary at the end shows some facts and characteristics of the aforementioned topologies which would be useful for future applications on MC topologies and control aspects. As mentioned before, MC has two main topologies including direct and indirect ones. The comparison between these two topologies made it clear that the two-stage matrix converters have advantages over the direct or conventional ones. For example, the possibility of reducing the number of switches forming the converter enables consumers to reduce the switching power losses and manufacturing cost as well. Less switching difficulties occurs because switches of the input stage (rectifier) can be turned on by the application of the zero vector current. The second stage is controlled as a standard inverter and the Clamp circuit can be simplified only by a capacitor in series with a diode which is not compatible with the direct matrix converter topology. Simulation results for an $\mathrm{RL}$ load supplied via a sparse matrix converter with the PWM modulation show that output voltage is controllable with corresponding improvements in power quality and the unity displacement power factor is achieved at the input stage. Eventually, these studies offer a very wide field of research, especially in the study of reliability, maintainability, availability; faults tolerances and stability of these types of converters.

\section{REFERENCES}

[1] Alesina, A. and Venturini, M. (April 1988) Intrinsic Amplitude Limits and Optimum Design of 9-switches direct PWM AC-AC converters, Proceedings of Power Electronic Specialist Conference, vol. 2, pp. 1284 1291.

[2] Alesina, A. and Venturini, M. (January 1989) Analysis and Design of Optimum Amplitude Nine-Switch Direct AC- AC Converters, IEEE Transactions on Power Electronics, vol. 4, no.1, pp. 101-112.

[3] Alesina, A. and Venturini, M. (1980) Generalised Transformer: A New Bidirectional, Sinusoidal
Waveform Frequency Converter with Continuously Adjustable Input Power Factor, IEEE Power Electronics Specialists Conference, pp. 242-252.

[4] Rmili, L., Rahmani, S., Fnaiech, F. and Al-Haddad, K. (2013) Space Vector Modulation Strategy for a Direct Matrix Converter, In Proc.14th international conference on Sciences and Techniques of Automatic control \& computer engineering - STA'2013, pp.1-6.

[5] Bradaschia, F., Cavalcanti, M., Neves, F. A. and Helber, E. P. (April 2009) A Modulation Technique to Reduce Switching Losses in Matrix Converters", IEEE Transactions on Industrial Electronics, vol. 56, no. 4, pp. 1186-1195.

[6] Choi, J. and Sul, S. (1995) A New Compensation Strategy Reducing Voltage/Current Distortion In PWM VSI Systems Operating With Low Voltages", IEEE IAS Annual Meeting, vol.31, pp. 1001-1008.

[7] Kang, J., Yamamoto, E., Ikeda, M. and Watanabe, E. (November 2011) Medium-Voltage Matrix Converter Design Using Cascaded Single-Phase Power Cell Modules, IEEE Transactions on Industrial Electronics, vol. 58, no. 11, pp. 5007-5013.

[8] Garcés, A. and Molinas, M. (January 2012) A Study of Efficiency in a Reduced Matrix Converter for Offshore Wind Farms, IEEE Transactions on Industrial Electronics, Vol. 59, no. 1, pp. 184-193.

[9] Klumpner, A. and Blaabjerg, F. (October 2003) Using Reverse Blocking lgbts in Power Converters for Adjustable Speed Drive, Proceedings of IEEE Industry Applications Conference, vol. 3, pp. 1516 1523.

[10] Klumpner, A., Nielsen, P., Boldea, I. and Blaabjerg, F. (April 2002) A New Matrix Converter Motor (Mcm) for Industry Applications, IEEE Transactions on Industrial Electronics, vol. 49, pp. $325-335$.

[11] Changliang, X., Yan, Y., Song, P. and Tingna, S. (January 2012) Voltage Disturbance Rejection for Matrix Converter-Based PMSM Drive System Using Internal Model Control, IEEE Transactions on Industrial Electronics, vol. 59, no. 1, pp. 361-372.

[12] Ortega, C., Arias, A., Caruana, C., Balcells, J. and Asher, G. M. (June 2010) Improved Waveform Quality in the Direct Torque Control of Matrix- Converter-Fed PMSM Drives, IEEE Transactions on Industrial Electronics, vol. 57, no. 6, pp. 2101-2110.

[13] Daning, Z., Sun, K., Huang, L., and Sasagawa, K. (2005) A Novel Commutation Method of Matrix Converter Fed Induction Motor Drive Using RBIGBT, Fourtieth. IEEE IAS Industry Applications Society Annual Meeting, pp. 2347-2354.

[14] Casadei, D., Serra, G., Tani, A., Trentin, A. and Zarri, L. (October 2005) Theoretical and Experimental Investigation on the Stability of Matrix Converters, IEEE Transactions on Industrial Electronics, vol. 52, no. 5, pp. 1409-1419.

[15] Yue, F., Wheeler P., and Clare, J. (March 2006) Relationship of Modulation Schemes for Matrix Converters, 3rd IET International Conference on Power Electronics, Machines and Drives, pp. 266270.

[16] Rodriguez, J., Rivera, M., Kolar, J. and Wheeler, P. (January 2012) A Review of Control and Modulation Methods for Matrix Converters, IEEE Transactions on Industrial Electronics, vol. 59, no. 1, pp. 58-70,

[17] Domes, D., Hofman, W.and Lutz, J. (September 1114, 2005) A First Loss Evolution Using a Vertical SicJFET and a Conventional Sic-IGBT in the Bidirectional 
Matrix Converter Switch Topology, European Conference on power Electronics and Application.

[18] Hojabri, H., Mokhtari, H. and Chang, L. (March 2011) A Generalized Technique of Modeling, Analysis, and Control of a Matrix Converter Using SVD, IEEE Transactions on Industrial Electronics, vol. 58, no. 3, pp. 949-959.

[19] Mahlein, J. , Weigold , J. , and Simon,O. (November 29-december 2, 2001) New Concepts for Matrix Converter Design, The 27th Annual conference of the IEEE Industrial Electronics Society IECON, vol.2, pp 1044-1048.

[20] Ibarra, I., Kortabarria, J. , Andreu, I., Martin, M. L. and Ibañez, P. (January 2012) Improvement of the Design Process of Matrix Converter Platforms Using the Switching State Matrix Averaging Simulation Method, IEEE Transactions on Industrial Electronics, vol. 59, no. 1, pp. 220-234.

Mahlein,J., Bruckmann , M., and Braun, M. (April 2002) Passive Protection Strategy for Drive System with Matrix Converter and Induction Machine, IEEE Transactions and Industrial Electronics, vol. 49, no. 2, pp. 297-303,

[21] Ishiguro, A., Furuhashi, T., and Okuma, S. (1991) A Novel Control Method for Forced Commutated Cycloconverters Using Instantaneous Values of Input LineTo-Line Voltage, IEEE Transactions on Industrial Electronics, pp.166-172,
[22] Schafmeister F. and Kolar, J. (January 2012) Novel Hybrid Modulation Schemes Significantly Extending the Reactive Power Control Range of All Matrix Converter Topologies with Low Computational Effort, IEEE Transactions on Industrial Electronics, vol. 59, no. 1, pp. 194-210.

[23] Rmili, L., Rahmani, S., Vahedi, H. and Al-Haddad, K. (June 2014) A Comprehensive Analysis of Matrix Converters: Bidirectional Switch, Direct Topology, Modeling and Control, In Proc. 23rd IEEE International Symposium on Industrial Electronics, IEEE-ISIE,

[24] Huang,X., Goodman, A., Gerada, C., Fang, Y. and Lu, Q. (September 2012) A Single Sided Matrix Converter Drive for a Brushless DC Motor in Aerospace Applications, IEEE Transactions on Industrial Electronics, vol. 59, no. 9, pp.3542-3552.

[25] Wheeler, P., Clare, J.C., Empringham, L., Apap, M., Bradley, K., Whitley C. and Towers, G. (June 2004) A Matrix Converter Based Permanent Magnet Motor Drive for an Aircraft Actuator System, Proceedings of IEEE International Electric Machines and Drives Conference, vol. 2, pp. $1295-1300$. 